FILOZOFIA

Roč. 75,2020 , č. 7

DOI: https://doi.org/10.31577/filozofia.2020.75.7.4

\title{
K FILOZOFICKÝM OTÁZKAM PRESADZOVANIA SOCIÁLNYCH PRÁV
}

\author{
EVA SMOLKOVÁ, Filozofický ústav Slovenskej akadémie vied, Bratislava, SR \\ SMOLKOVÁ, E.: On the Philosophical Issues of Implementing Social Rights \\ FILOZOFIA, 75, 2020, No 7, pp. $555-568$
}

\begin{abstract}
The issue of human rights and especially social rights is one of the most complex, intricate, and, at the same time, one of the most common topics of contemporary philosophy. It brings forward traditional philosophical themes of justice and equality, questions of bridging the moral and legal aspects of providing equal opportunities for everyone. The diversity of philosophical underpinnings of social rights allows theorists to grasp the issue from different perspectives and to introduce readers to the possibilities of accepting social rights such as the recognition of human dignity, equal opportunities, and equal chances in life. Social rights provide a way of restoring justice and opportunities for those who would not otherwise have it at all. In principle, however, it does not decide how social rights are designed, but how they are implemented and whether they are enforceable, ie, how the system of social services is set up in a state and what approaches states choose in implementing social rights and whether these adequately provide social guarantees for human existence, dignity, life, equal opportunities and prevention of social exclusion.
\end{abstract}

Keywords: Human rights - Social rights - Justice - Equality - Dignity of human existence

Myslím, že má-li člověk pochopit mocnou sílu skrytou v myšlence lidských práv, musí sám na sobě zažít, co to je, když jsou mu tato práva upírána.

Stanislav Sousedik

\section{Na úvod}

Problematika l'udských práv je jednou z najfrekventovanejších tém v sociálnej filozofii a etike, má svoju nezastupitel'nú rolu pri tvorbe kritérií normativity tak v rovine morálnej, ako i právnej, a samozrejme súvisí s miestom a postavením človeka v l’udskej spoločnosti. L’udské práva sú koncipované na základe presvedčenia o potrebe rovnakých šancí pre každého, vychádzajú z ideí rovnosti a predstáv o rovnosti šancí 
pre všetky l'udské bytosti. Primárne ide o tie práva, ktoré obsahovala V̌̌eobecná deklarácia ludských práv, ${ }^{1}$ ktoré sa premietli do ústav väčšiny demokratických štátov a sú ukotvené v medzinárodných zmluvách a dohovoroch. Pojem l'udské práva sa vztahuje na označenie rôznych typov práv, ktoré sa označujú ako hospodárske / ekonomické, kultúrne a sociálne. V tomto článku sa budeme zaoberat' najmä tými právami, ktoré obsahujú sociálne záruky dôstojnej l'udskej existencie a sústredíme sa na filozofické hl’adisko problematiky, otázky spravodlivosti a rovnosti v rámci problematiky sociálnych práv. Budeme používat' termín sociálne práva aj napriek tomu, že je výstižnejšie hovorit' l'udských právach, ktorých ciel'om je vyrovnávanie sociálnych rozdielov. Pojem sociálne práva je totiž zaužívaný a používa sa v oficiálnych dokumentoch aj v názvoch príslušných úradov či komisie OSN. Sociálne práva sú tými právami, ktoré majú za ciel' zaručit' každému človeku dôstojnú existenciu, a teda taký rozsah základných životných podmienok, ktoré sú nevyhnutné pre dôstojný - môžeme použit' aj termín plnohodnotný - život. Uvedené práva sú síce odvodzované od Všeobecnej deklarácie l'udských práv, ${ }^{2}$ ale historicky je väššina z nich podstatne staršia. Ich filozofické korene siahajú do osvietenstva a ako sociálne práva sa začali na politickej scéne presadzovat' v Európe koncom devätnásteho storočia. ${ }^{3}$

V kontexte problematiky l'udských práv treba povedat', že všetky l'udské práva „nadobúdajú podobu nárokov, oprávnení, slobôd, kompetencií, imunity“. Napriek tomu, že sa používajú vo vztahu k l’udským právam rozlišovacie kritériá a delia sa na práva občianske, ekonomické, sociálne či kultúrne, všetky sú navzájom prepojené a hranica medzi nimi nie je ostrá. Väčšinou dokonca platí, že izolovane sa nemajú a nedajú uplatňovat', pretože majú väzbu na ostatné. ${ }^{4}$ Zároveň platí, že za počiatok presadzovania l'udských práv v demokratickej spoločnosti sa pokladá rok 1945. Systém l’udských práv nie je uzavretým systémom, preto l'udské práva postupne zahŕ-

\footnotetext{
${ }^{1}$ V̌seobecná deklarácia l’udských práv: Dostupné online na: https://www.ohchr.org/EN/UDHR/Documents/UDHR_Translations/slo.pdf

${ }^{2}$ V článku 25 Všeobecnej deklarácie l’udských práv sa píše: Každý má právo na životnú úroveň zabezpečujúcu jemu i jeho rodine zdravie a blahobyt vrátane potravy, šatstva, bývania, lekárskej starostlivosti a nevyhnutných sociálnych opatrení; má právo na zabezpečenie v nezamestnanosti, $\mathrm{v}$ chorobe, pri pracovnej nespôsobilosti, pri ovdovení, v starobe alebo $\mathrm{v}$ ostatných prípadoch straty zárobkových možností, ktoré nastali okolnost’ami nezávislými od jeho vôle. Dostupné online na: https://www.ohchr.org/EN/UDHR/Documents/UDHR_Translations/slo.pdf

${ }^{3} \mathrm{~V}$ roku 1881 kancelár Otto von Bismarck začal uskutočňovat’ sociálne reformy a zaviedol systém povinného poistenia pre tie skupiny obyvatel'ov, ktoré boli sociálne ohrozené. Ciel'om bolo zabránit' hrozbám spojeným so sociálnymi problémami obyvatel'ov Nemecka a zaručit' spoločenskú stabilitu a sociálny zmier.

${ }^{4}$ To sa prejavuje aj v praktickej rovine tým, že je zriadený Výbor OSN pre hospodárske, sociálne a kultúrne práva.
} 
ňajú d’alšie skupiny osôb, ktoré v pôvodných dohovoroch neboli explicitne pomenované. Ako príklad môžeme uviest' osobitú ochranu detí, žien, starších l'udí osôb so zdravotným postihnutím a podobne. ${ }^{5}$

\section{Sociálne práva}

Sociálne práva upravujú sociálne záruky l’udskej existencie. Tieto práva sú nástrojom štátu a ich primárnym účelom je stat' sa prevenciou sociálneho vylúčenia. $V$ diskusiách o týchto právach sa používa rozdelenie na osem základných sociálnych udalostí, ktoré môžu v priebehu života človeka nastat' a ktoré môžu mat' vplyv na kvalitu jeho života. Je to rodičovstvo a materstvo, potreba zaopatrit' rodinu, choroba alebo úraz, invalidita, staroba, smrt', nezamestnanost' a chudoba. Zavedenie sociálnych práv do štátnej legislatívy má za ciel' zaistit' každému občanovi, aby jeho životné podmienky boli dôstojné a fungoval systém sociálneho zabezpečenia tak, aby mu ich pomohol zvládnut' v prípade, že nemá ideálnu štartovaciu pozíciu, alebo v priebehu jeho života nastanú nepredvídatel'né okolnosti či situácie, ktoré nie je schopný vlastnými silami zvládnut'. Ideovým základom takéhoto konceptu je predpoklad, že každý človek má právo rozvinút' svoje schopnosti, naplnit' svoj potenciál a mat' možnost' viest' dôstojný život.

Otázky, ktoré súvisia s právami jednotlivcov a usporiadaním spoločnosti, sa vo filozofii objavovali prakticky od jej vzniku. Budeme presadzovat' názor, že filozofické, najmä morálne zdôvodnenia sú klúčové aj pre zdôvodnenie l'udských práv a o ich spoločenskej potrebe nie sú v morálnej filozofii pochybnosti. Problémom je uchopit', ktoré práva majú a musia byt' považované za sociálne. Že to nie je jednoduché, dokazujú rôzne vymedzenia, a najmä interpretácie toho, čo je možné za sociálne právo považovat'. Samo vymedzenie sociálnych práv je pomerne zložité, preto musíme siahnut' po základnej kategorizácii l’udských práv. Autorky T. Sedová a Z. Palovičová (Sedová, Palovičová 2017,31) hovoria o „katalógu l'udských práv, kam zarad’ujú substitučné práva (život, výživa, bývanie, zdravie, voda, primeraná životná úroveň). Pollmann a Lohmann (Pollmann - Lohmann 2017, 272) súhlasia, že ide o substitučné práva, ale upozorňujú na ich súvislost's inými právami, napríklad zásadou rovnakého zaobchádzania. Nemecký teoretik M. Krennerich k sociálnym právam zarad’uje právo na život, výživu, bývanie, zdravie, vodu a primeranú životnú úroveň (Krennerich 2013, 10). Iní autori radia k sociálnym právam aj právo na prácu, právo na uspokojivé pracovné podmienky, právo na životnú úroveň a na rodinu. Ako vidiet' z uvedeného, jednoznačné vymedzenie absentuje. Dôvodov je hned' niekol'ko. Jednak je zložité stanovit' „hranicu“ medzi jednotlivými právami, ${ }^{6}$ pretože všetky ludské

\footnotetext{
${ }^{5}$ Bodom obratu bola v tomto kontexte Viedenská konferencia o l’udských právach v roku 1993.

${ }^{6}$ Napríklad právo na vzdelanie je t’ažké oddelit' od práva na sociálne zabezpečenie a právo na spravodlivé pracovné podmienky úzko súvisí s otázkami diskriminácie.
} 
práva spolu súvisia a je problematické ich vymedzit’ tam, kde obsah pojmov nie je jednoznačný a termíny sú nejasné alebo viacznačné. Ak sa pozrieme napríklad na obsah termínu zdravie ${ }^{7}$ a slovné spojenie právo na zdravie, ktoré je uvedené ako sociálne právo, tento pojem vyvoláva viac otázok ako odpovedí. ${ }^{8}$ Podobné je to aj s vymedzením primeranej životnej úrovne či iných pojmov, ktoré navyše vždy treba vzt'ahovat' s ohl'adom na jednotlivca, ktorého sa týkajú.

Sociálne práva nie sú ,,predpisy, návody ani vzory“ a neurčujú, ako sa má spoločnost' zachovat' pri ich implementácii, pretože tá závisí od inštitucionálneho zázemia a empirickej podoby spoločensko-politického koncenzu (Palovičová 2017, 69). Predpokladá sa, že implementácia sociálnych práv by mala pokrývat' základné existenčné potreby každého človeka. Tie sa však v rozličných krajinách líšia. Zodpovednost' rešpektovat', chránit' a zaručovat' l'udské práva majú štáty v kompetencii v rámci svojej suverenity, a táto zodpovednost' je horizontálna i vertikálna, čo znamená, že ide o zodpovednost' dovnútra i medzi štátmi (Kälin, Künzli 2008, 108). Zodpovednost'ou štátu je vytvorit' podmienky na dôstojný život svojich občanov, a teda zabezpečit' služby spojené s ich výkonom. Niektorí americkí autori tvrdia, že sociálne práva predstavujú nezáväzné politické výzvy, pretože tieto sú formulované všeobecne a vymožitel'né len nepriamo (Krennerich 2013, 118). V literatúre o sociálnych právach sa často objavuje argument, že sociálne práva nie sú „skutočnými“ l'udskými právami (Krennerich 2013, 108 a n.). Dokonca sa argumentuje, že ide o povinnosti bohatých štátov, pretože náklady na implementáciu sociálnych práv zat’ažujú štátne rozpočty a vyžadujú existenciu cielených politík a poskytovanie nákladných sociálnych a zdravotníckych služieb.

Problematika sociálnych práv je principiálne zložitejšia ako je to u práv občiansko-politických, ktoré sú známe ako klasické l’udské práva. Sociálnym právam sa zvykne hovorit' aj „l'udské práva druhej generácie“ a sú výdobytkom historického boja za emancipáciu a spravodlivost'. O sociálnych právach teda možno uvažovat' ako o vymožených dôsledkoch. Väčšina $\mathrm{z}$ nich $\mathrm{v}$ určitej miere ovplyvnila spoločenské vzt’ahy v prospech tých, ktorí žiadne sociálne práva predtým nemali, alebo im boli upierané. Právne normy stanovia, nakol'ko sa stanú súčast’ou právneho poriadku toho-ktorého štátneho útvaru. Morálna filozofia a etika skúmajú mieru pozitivity (dobra) zákonov, ktoré vyjadrujú podla zákonodarcu l'udské práva v súlade s ich mravnou

${ }^{7}$ Zdravie je stav organizmu ktorý určujú medicínske kritériá, ktoré sú funkčnými kritériami. Reálne teda právo na zdravie nemôže byt' distribuované, lebo je to individuálna dispozícia každého jednotlivca a definuje sa ako „stav úplnej telesnej, duševnej a sociálnej pohody“ Podl'a: Ústava Svetovej zdravotníckej organizácie (WHO). Dostupné online na: https://www.who.int/about/finances-accountability/ funding/assessed-contributions/en/ (Navštívené: 22. 8. 2020).

${ }^{8}$ Zastávame názor, že právo na zdravie nejestvuje, lebo zdravie nevie garantovat' žiadny systém. Jestvuje len právo na zdravotnú starostlivost', špecifikované v zákonných ustanoveniach vo vymedzenom rozsahu.

${ }^{9}$ Publikácia autorov Holmes a Sustein nesie názov: Náklady na práva: Prečo sloboda závisí od daní? 
predlohou. Ak budeme pokladat' za jednoduché vymedzit' morálny základ l'udských práv, ${ }^{10}$ a teda opodstatnenost' ich zavádzania do právneho systému, stretneme sa s problémom ich vymožitel'nosti, teda právnym problémom. Vymožitel'nost' závisí od viacerých faktorov, v prvom rade od toho, či a ako sú nastavené kompenzačné funkcie štátu a ako fungujú inštitúcie, ktoré majú zabezpečovat' služby vo verejnom záujme. Akceptácia sociálnych práv štátom totiž automaticky neznamená, že tieto práva sú aj nárokovatel'né či vymožitel'né. Závisí to od rozsahu právneho politického zasahovania do systémov poskytovania služieb a od toho, či je alebo nie je zabezpečená ich finančná realizovatel'nost'. Koncept sociálnych práv akoby závisel od dvoch základných faktorov, od toho, aký „obraz človeka“11 má štát o svojom vlastnom občanovi a jeho sociálnych právach, a od toho, či sú vyčlenené zdroje na zabezpečenie sociálnych potrieb občanov. Preto sa jednotlivé modely od seba líšia a implementácia toho istého a tak isto deklarovaného práva má $\mathrm{v}$ rôznych štátoch rozdielnu podobu. Aktuálna podoba sociálnych práv $\mathrm{v}$ štáte závisí teda nielen od legislatívy, ale aj od kultúrnych a morálnych princípov platných $\mathrm{v}$ spoločnosti. Právna norma totiž môže viest' $\mathrm{k}$ deformácii právnej praxe realizovanej v tom-ktorom štáte. ${ }^{12}$ Osobitne v podmienkach výrazných sociálnych nerovností môžu byt’ štrukturálne obmedzenia dôsledkom nerovnomerne rozložených príležitostí pre život a rozvoj. Každé z jestvujúcich sociálnych práv má svoje špecifiká a ich implementácia vyžaduje funkčnú stratégiu na úrovni štátu a predpokladá následné naformulovanie ciel'ov štátnej politiky a funkčných vlastností systému, ktorý takto vzniká. ${ }^{13}$

Je možné historicky uchopit' vznik jednotlivých sociálnych práv, ako aj dôvody, prečo sa postupne presadzovali na pozadí konkrétnych sociálnych pohybov. Sociálne práva sú označované aj ako „druhá vlna“ l’udských práv alebo práva „druhej generácie“. Väčšina teoretikov ich vníma pozitívne a ich zavádzanie posudzuje ako „dobro“, pozitívnu spoločenskú zmenu, aplikáciu princípov rovnosti a spravodlivosti. Prijímanie sociálnych práv štátom a ich implementovanie do právneho systému zvyšuje právne nároky občanov voči štátu a poskytuje určitým skupinám či jednotlivcom takú mieru slobody, ktorú by inak, vlastným pričinením a silami, dosiahnut' nemohli. Vznik takýchto normatívnych kritérií súvisí s otázkou rešpektu, ochrany a záruk, ktoré by mal

${ }^{10}$ Nie každý autor morálne východiská l'udských práv vie a môže uchopit'. Tugenhadt priznáva, že zdôvodnit' mravné normy a l'udské práva, ktoré sú ich čast'ou, nedokáže, ale jeho empiristická metafyzika bez akcentu potreby spravodlivosti neumožňuje tieto myšlienkové východiská. Pozri E. Tugendhat: Přednášky o etice. Praha: Oikúmenh 2004.

${ }_{11}$ Tento termín použiva M. Krennerich.

12 V socialistických krajinách bolo právo na prácu pretransformované do povinnosti pracovat'. Príkladov z nacistického Nemecka či Sovietskeho zväzu, ale aktuálne aj Severnej Kórey možno uviest' viac.

${ }^{13} \mathrm{~V}$ rámci sociálneho zabezpečenia možno identifikovat' tri systémy: 1. sociálne poistenie, 2 . systém štátnej sociálnej podpory a 3. systém sociálnej pomoci pre občanov, ktorí sa ocitnú bez príjmu. 
štát uplatnit' voči svojim občanom. Tým je zároveň povedané, že sociálne práva sú $\mathrm{v}$ prenesenom zmysle slova implementáciou ideí rovnosti, a samozrejme spravodlivosti do právneho systému.

Morálny základ ludských práv je odvodzovaný od osvietenstva a viazaný na vznik a presadzovanie princípov morálnej filozofie. Väčšina sociálnych práv však vznikala v konkrétnom historickom období na pozadí zlých skúsenosti so štrukturálnou nespravodlivostou, často v reakcii na negatívne zmeny a zlé životné podmienky určitých sociálnych skupín l’udí. Vzhl’adom na to, že jestvuje pomerne rozsiahla literatúra, venovaná kreovaniu sociálnych práv v európsko-americkej kultúrnej oblasti, ${ }^{14}$ najmä v priebehu devätnásteho a na začiatku dvadsiateho storočia na pozadí priemyselnej revolúcie, nebudeme túto historickú problematiku skúmat'. Spomenieme však, že snaha napravovat' sociálne rozdiely spôsobené chudobou je znakom demokratickej spoločnosti. Vzhl'adom na to, že spoločenské procesy sú podmienené procesom kolektívneho učenia, menia sa aj predstavy o tom, koho sa majú a môžu týkat' sociálne práva. Rozširujú sa (alebo sú vyňaté zo systému) skupiny osôb, ktoré majú nárok na konkrétny typ sociálneho zabezpečenia v rozličnom rozsahu. Vynárajú sa nové potreby špecifických skupín. Je teda nielen možné, ale aj vel'mi pravdepodobné, že sociálne práva sa budú priebežne modifikovat', menit' zoči-voči novým typom hrozieb alebo faktorom nespravodlivosti, ktoré sa v modernej spoločnosti vynoria a budú vyžadovat' sociálne riešenia.

Zmeny v spoločnosti, aj v súvislosti s l’udskými právami, prebiehajú nepretržite. To dokazujú aj takzvané práva „tretej generácie“(Vasak 1977). V súvislosti s nimi sa hovorí o „tretej vlne l’udských práv“. Vznik týchto práv sa kladie do druhej polovice dvadsiateho storočia a dostali označenie kolektívne práva. Medzi ne sa zarad’uje právo na rozvoj, mier a čisté prostredie. Ako o l'udských právach sa o nich začalo uvažovat' až v druhej polovici dvadsiateho storočia, niektoré sa $\mathrm{v}$ právnych systémov etablovali až v devät'desiatych rokoch. Väčšina $\mathrm{z}$ nich má nepopieratel'nú väzbu na sociálne práva $^{15}$ (Krennerich 2013,20), aj ked' diskusia v tomto smere ešte len prebieha.

Spomínali sme, že väčšina sociálnych práv vznikala v euro-americkom prostredí na základe konkrétnych skúseností, zoči-voči útlaku a sociálnej nespravodlivosti. Vznikali teda na základe skúsenosti. Takzvaná „tretia“ vlna l'udských práv vzniká inak, často aj bez negatívnej skúsenosti, presnejšie preto, aby sa negatívnej skúsenosti zabránilo. Právo na zdravé životné prostredie legislatívy štátov zavádzajú do svojich právnych poriadkov aj vtedy, ked' nejestvujú negatívne skúsenosti s devastáciou životného prostredia, hoci v období klimatických zmien je to skôr ilúzia. Pri práve na zdravé životné prostredie i práve na rozvoj je evidentný ich sociálny rozmer. Garantom

${ }^{14}$ A. Sen vo svojej publikácii The Idea of Justice spochybňuje, že historické počiatky l’udských práv sú plodom západnej tradície prirodzeného práva.

${ }^{15}$ Ide o právo na rozvoj, na mier, na čisté (zdravé) životné prostredie či právo na garantovaný príjem. 
týchto práv je opät' štát, ale postupne sa vynára potreba nadnárodného kontextu, a teda rovnakej (minimálne podobnej) implementácie v rôznych štátoch. Podl’a Millera (Miller 1995, 186) „„̌lovek nepotrebuje víziu globálneho občianstva“, ale je žiaduce túto ideu preferovat', pretože etický partikularizmus vedie k priorizovaniu vlastných občanov a ich záujmov, no práve v oblasti distribúcie prírodných zdrojov sa ukazuje, že „ak to znamená pokles životnej úrovne v bohatých krajinách, možno ju odmietnut' s argumentom, že povinnosti voči spoluobčanom sú dôležitejšie než tie, ktorými sú zaviazaní cudzincom“ (Palovičová 2014, 58).

\section{Sociálne práva, spravodlivost' a princíp rovnosti}

Zavádzanie daní a obmedzení pri vykonávaní určitých podnikatel'ských aktivít a záväzky štátu, aby vytvoril funkčný systém zdravotného či sociálneho poistenia, vyžaduje presmerovanie finančných tokov na aktivity, ktoré nie sú ziskové. To je hlavný dôvod, pre ktorý interpretácia l'udských práv, primárne tých sociálnych, závisí od distributívnych nástrojov, a to najmä v tých prípadoch, ked’ sú do distributívnej schémy zahrnuté aj nemateriálne statky implementované do systému sociálnej spravodlivosti. ${ }^{16}$ Záleží teda na vhodnej konceptualizácii pojmu spravodlivost' a rovnost' a na tom, ako a či vôbec sú nastavené pravidlá spoločenského usporiadania vo vzt’ahu k otázke spravodlivosti a rovnosti šancí. Napriek tomu, že pojmom akými sú dôstojný život či kvalita života ${ }^{17}$ rozumieme intuitívne, terminologicky zadefinovat' ich nie je jednoduché (Gosepath 2001), nehovoriac o tom, že preferencie jednotlivcov sa môžu rôznit'.

V zásade platí, že problematika sociálnych práv je interdisciplinárna a v podstatne väčšej miere než filozofické, sú známe politologické, právne, sociologické a ekonomické pohl'ady na danú problematiku. Filozofia, ako sme už naznačili, analyzuje problematiku sociálnych práv so zorného uhla spravodlivosti, čo ako sme predikovali je tradičná filozofická téma a úzko súvisí s problematikou rovnosti šancí. Morálna filozofia, konkrétne etika, pracuje v kontexte s problematikou l’udských práv s predstavami o spoločnom a individuálnom dobre.

Ked'že, ako sme už naznačili, ide o jeden z najstarších problémov filozofie, neprekvapuje, že jestvuje niekol'ko línií interpretácie spravodlivosti a možno identifikovat' rôzne názorové prúdy. Bez ohl'adu na to, ktorý je preferovaný, treba si uvedomit', že všetky úvahy o spravodlivosti predpokladajú existenciu morálnych kritérií rozhodovania. Diskusia o tom, či je etická norma minimom tej právnej alebo naopak a o tom, že právne normy sa kreujú nezávisle od morálnych normatívnych kritérií, prebieha desat'ročia. V kontexte problematiky sociálnych práv možno uchopit' obidva

\footnotetext{
${ }^{16}$ Problém spravodlivosti sa netýka len materiálnych statkov.

17 V obidvoch prípadoch sa skôr vymedzuje, čo nie je dôstojný život a čo je choroba, než aby sa špecifikovali pojmy tak, ako sme ich uviedli.
} 
prístupy. Je to rozhodovanie na základe morálnej skúsenosti, aj pri jej absencii. V zásade platí, že to, čo odporuje mravnému cíteniu je vel'mi t’ažké, ak nie nemožné presadit' ako normu, ktorá by aj reálne fungovala a bola akceptovaná. Je možné siahnut' po etickom diskurze a dopracovat' sa ku koncenzu (Habermas 2003). Požiadavka, aby sme sa v prípade rozdielnych záujmov usilovali o dorozumenie $\mathrm{v}$ rámci diskurzívnej etiky je isto mravne prijatel'ná, niektorí autori však priznávajú, že „zdôvodnit' mravné normy a l'udské práva, ktoré sú ich čast'ou, nedokážu (Tugendhadt 2004). Štátnych predstavitel'ov zvyčajne nič nezaväzuje prizývat' k diskusii aj tých, ktorých sa majú konkrétne opatrenia či zákonné normy týkat', spravidla sa diskusia vedie medzi predstavitel'mi l'avice a pravice. Zriedkakedy sa dáva prednost' komunikatívnemu jednaniu pred direktívnym, ak sa to deje, tak len v rámci politického diskurzu predstavitelov štátu. Každé z jestvujúcich sociálnych práv má svoje špecifiká a implementácia každého jedného práva vyžaduje kreovat' a manažovat' iné inštitúcie. V tomto kontexte je ešte potrebné upozornit' na to, že vytvorené inštitúcie musia v záujme naplnenia ciel'a presadzovat' sociálne práva spolu aj efektívne komunikovat'. ${ }^{18}$

Problematika spravodlivosti je z dejinno-filozofického hl'adiska jednou z najstarších tém. Ideou spravodlivosti sa zaoberal už Aristoteles. Uvažovanie o rozdiele medzi spravodlivým a nespravodlivým človekom na pozadí posudzovania spravodlivého konania ako zákonného konania je pre Aristotela charakteristické, rovnako ako úvahy o tom, aké rozhodnutia vo vzt’ahu k prerozdeleniu statkov sa pokladajú za spravodlivé, čo v Aristotelovom jazyku znamená primerané (Aristoteles 129 a n.). Hoci by bolo vel'mi odvážne Aristotelove idey pokladat' za základ konceptu l'udských práv, bol to práve on, kto upozornil na to, že nestrannost' neznamená rovnost' a ako prvý identifikoval základný rozdiel medzi korektívnou a distributívnou spravodlivost'ou. K problematike rovnosti treba upozornit' na vklad myslitel'ov Vel'kej Francúzskej revolúcie, najmä Jeana-Jacquesa Rosseaua. ${ }^{19}$ Rozlíšenie vzt’ahu človeka ako bytosti, ktorá má konkrétnu vôlu a občana, bolo pre koncipovanie sociálnych práv v európskom kontexte klúčové. Známy je jeho výrok, že vzájomný styk medzi l'ud’mi vyžaduje premenu prirodzenej slobody na mravnú slobodu.

Problematika spravodlivosti a rovnosti príležitostí rezonovala vo filozofii prakticky od jej vzniku. „V súčasnom filozofickom diskurze sa vyprofilovali štyri hlavné línie interpretácie spravodlivosti: koncepcie distributívnej spravodlivosti sledujúcej

\footnotetext{
${ }^{18} \mathrm{~V}$ rámci sociálneho zabezpečenia možno identifikovat' tri systémy: 1. sociálne poistenie, 2. systém štátnej sociálnej podpory a 3 . systém sociálnej pomoci pre občanov, ktorí sa ocitnú bez príjmu.

${ }^{19}$ Rousseaove diskurzy o pôvode a príčinách nerovnosti medzi l'ud'mi (Discours sur les Sciences et les Arts, Discours sur l'origine et les fondments de l'inegalite a Du Contract Social) zásadne ovplyvnili chápanie rovnosti a spravodlivosti. Pozri Rousseau, J. J. (2010): O pôvode a prícinách nerovnosti medzi l'ud'mi. Bratislava: Vydavatel'stvo spolku slovenských spisovatel'ov.
} 
princípy férovej distribúcie a redistribúcie“ (Palovičová 2014, 10). Z morálneho hladiska sú dôležité tie právne otázky, ktoré majú presah do etickej roviny. „Právne dokumenty sú síce pre dodržovanie l’udských práv klúčové, sú však niečím ako,vonkajším obalom', tvrdeniami, ktoré bez identifikácie morálnych súvislostí a väzieb, ktoré v spoločnosti fungujú historicky, alebo na základe skúsenosti, ${ }^{20}$ vzbudzujú pochybnosti.“ Najčastejšie sa stretávame s pochybnost'ami o tom, či niektoré články, napríklad V̌seobecnej deklarácie l’udských práv, nepresahujú princíp univerzálnej platnosti l'udských práv, ktoré patria každému človeku práve preto alebo len preto, že je človekom. Z hl'adiska filozofie to je téma, ktorou sa zaoberal John Locke, a neskôr Imanuel Kant, autori, ktorí pokladali človeka za vlastníka prirodzených práv. Thomas Hobbes a po ňom i John Rawls viazali práva človeka na existenciu spoločenskej zmluvy. Tradícia spoločenskej zmluvy je charakteristická pre všetky liberálne prístupy. Liberálne stanoviská sa však stali predmetom sporov o základné morálno-politické otázky a viedli k sformulovaniu komunitarizmu a zdiel'aných hodnôt (presnejšie hodnotových orientácií), prostredníctvom ktorých možno zadefinovat' spoločenstvo. Spôsob, akým sa definujú východiskové princípy platnosti l'udských práv, je zásadný pre otázky spravodlivosti, l'udské práva však tematicky pracujú, okrem princípu spravodlivosti, aj s ideou rovnosti, a to rovnosti v rôznych významoch.

Zvyčajne sa rozlišujú tri významy rovnosti. 1. formálna - ide o rovnost' pred zákonom, 2. rovnost' príležitostí v zmysle rovnakých šancí na získanie takých schopností alebo zdrojov, ktoré sú významné pre sledovania individuálnych záujmov, a 3. rovnost' výsledkov, ktorá sa týka vyhodnocovania distribúcie verejných statkov a bremien v určitom časovom úseku. Aká je teda jednotka rovnosti, respektíve nerovnosti? Dajú sa vôbec stanovit' a určit' porovnávacie kritériá, ktoré by umožňovali interpersonálne porovnávanie? Rawls je autorom modelu hypotetickej situácie počiatočnej pozície rovnosti, v ktorej je každý slobodný. Rovnost' je stav, v ktorom platí taká dohoda, ktorá je koncipovaná na základe princípov férovosti a spravodlivosti. Podla toho by mala mat' každá osoba rovnaké práva. Nerovnosti v príjmoch sú však reálne, čo v praxi znamená, že majetnejší by mali prispievat' do systému viac. Rawls to pokladá za ospravedlnitel'né (legitímne), pretože to prináša prospech aj znevýhodneným jedincom (Rawls 2007, 126). V kontexte problematiky sa ale nemožno spoliehat' na kontraktualistické premisy, je možné rozšririt' teóriu spravodlivosti tak, aby sa dala zabezpečit' rovnost' príležitostí aj pre zranitel'né skupiny obyvatel'stva? Pri presadzovaní sociálnych práv možno vychádzat' $z$ Rawlsových primárnych foriem dobra postavených na teórii spravodlivosti a slušnosti. $V$ jej rámci sa špecifikujú férové podmienky racio-

${ }^{20} \mathrm{~V}$ kontexte práv takzvanej tretej generácie sme sa zmieňovali aj o tom, že je možné negatívnej skúsenosti aj predchádzat'. 
nálnej kooperácie slobodných a rovných bytostí (Rawls 2007, 27). Iní autori však presadzujú ako kritérium vlastnenie statkov (napríklad príjem), d’alší porovnávajú nerovnosti v jednotkách blahobytu (well-fare), čo ale indikuje subjektívny pocit dostatočnosti. A. Sen uvažuje v kategóriách reálnych možností (capabilities), pokladá demokraciu za „vládu na základe diskusie“ a „verejného zvažovania“ (Sen 2010, 325), čo je pravdepodobne inšpirované Tugendhatom, ale na rozdiel od jeho konceptu aj využitel'né pri implementácii sociálnych práv. Sen ponúka možnost' prekonat' formálne štruktúry a kontraktualistické premisy, pretože do svojej koncepcie zapracoval aj požiadavku hodnotenia nespravodlivosti, aj ked' zostáva nejasné, či je potrebné hodnotit' nespravodlivost' v oblasti spôsobilostí, alebo na základe funkčného zlyhania. Ako však zmerat' spôsobilosti? ${ }^{21}$ Sen sám začal neskôr uvažovat' o viacerých distributívnych pravidlách a zameral sa na návrhy ako urobit' spoločnost' spravodlivejšou. Zostáva však otázne, či je spôsobilost' dimenziou blahobytu a či je vôbec možné spravodlivost' hodnotit'.

Je vlastne možné vyvarovat' sa preferovaniu vlastných záujmov a predsudkov a nastavit' kritériá spravodlivosti ako férovosti? (termín spravodlivost' ako férovost' používa A. Sen; Sen 2010, 54). Princípy spravodlivosti by mali byt' výsledkom dohody slobodných, racionálne uvažujúcich l’udí, vedomých si svojich i cudzích záujmov, ktorí sa dohodnú na pravidlách koexistencie. Objektivita a nestrannost' by mali byt' základom spravodlivosti (Rawls 2007). Implementácia princípov spravodlivosti však prináša množstvo rôznorodých problémov, z nich niektoré nemožno predvídat'.

Dôležitá je stratégia implementácie princípov spravodlivosti pri vytváraní a manažovaní systémov sociálnej starostlivosti a zabezpečení spravodlivosti v sociálnych vzt'ahoch. Ponúkat' konkrétne riešenia je potrebné na elimináciu všetkých nerovností, pritom niektoré môžu byt špecifické. Na tie systém musí vediet' operatívne reagovat'. Treba volit' také koncepčné nástroje, ktoré sú $\mathrm{k}$ dispozícii, a zapracovat' do systému istú mieru flexibility. Dokonale spravodlivá spoločnost' totiž nejestvuje a verifikáciu spravodlivosti môžeme urobit' len post festum prostredníctvom meratel'ných kritérií. A aj tie sú väčšinou kvantitatívne, a nie kvalitatívne. Práve preto potreba identifikácie sociálnych potrieb nepostačuje, musíme brat' do úvahy rozdiely medzi jednotlivcami. Predstavy o rovnosti príležitostí sa u jednotlivcov líšia, limity sú dané pohlavím, vekom, sociálnou skupinou, v ktorej žijeme a d'alšími premennými, ktoré nás determinujú a podmieňujú odlišnost' potrieb. To implikuje odlišné formy dobra v záujme dosiahnutia tých istých ciel'ov, čo vyplýva z diverzity potrieb. Zabezpečovat' prerozdel’ovanie zdrojov je však v súčasnosti možné len vnútri systému, z čoho vyplýva, že mimo štátnych hraníc môžu byt' princípy spravodlivosti bezpredmetné. Podla Sena sú

${ }^{21}$ Diskusia v tomto smere ešte len prebieha a najväčšou nierou k nej prispela W. Kuklysová 2005. 
l'udské práva nárokmi jednotlivca na spravodlivú formu spoločenského poriadku, a tá by nemala byt' zodpovednost'ou len jedného štátu.

Všetky koncepty, ktoré sme predstavili, vykazujú principiálne uznanie rovnosti, reálne však len niekol'ko autorov, medzi nimi Sen, Nussbaumová, a v neposlednom rade aj slovenské autorky Palovičová a Sedová, sa intenzívne snažili o to, aby upozornili na problém nerovnosti štartovacích podmienok, a to najmä u l'udí so zdravotným postihnutím. Zastávajú názor, že treba určit' objektívne kritériá a odpovedat' na otázku, či pri distribúcii či redistribúcii má, alebo musí byt' pozornost' venovaná aj postaveniu tých, ktorí sú adresátmi sociálnych práv. Z liberálnych kruhov však zaznieva názor, že je podstatný vzájomný pomer miery chudoby a bohatstva. Ten sa však môže menit', napríklad pod vplyvom krízy sa štátna administratíva môže rozhodnút', že sa systémy sociálneho a zdravotného zabezpečenia budú modifikovat' v neprospech tých, ktorí sú odkázaní na ich služby. ${ }^{22}$

\section{Záver}

Efektívna ochrana l'udských práv teda predpokladá efektívnu štátnu moc. Štáty prebrali úlohu ich garanta a musia zmluvný záväzok dodržat'. Zmluvy o l'udských právach vzájomne zaväzujú zmluvné strany, takže každá zmluvná strana môže od tej druhej vyžadovat' plnenie zmluvy. Oprávnenými a uprednostňovanými žiadatel'mi sú však spravidla jednotlivci. Princíp vzájomnosti však v takom prípade zlyháva, pritom je pri presadzovaní práv nevyhnutný. Štátu, ktorý nedodržiava l'udské práva, sa nijako nedotkne, ked' druhá zmluvná strana reaguje tak, že nedodrží svoje l'udskoprávne záväzky. ${ }^{23}$ To má však svoje dôsledky. Preto sa l’udské práva čoraz častejšie pokladajú za objektívne predpisy, ktoré ich - štáty - nezaväzujú k tomu, aby ich aj reálne implementovali (Pollmann - Lohmann 2017, 148). Právo poskytuje jeho držitel'ovi určitý nárok a adresátov práva zaväzuje k určitému správaniu. Mat' právo znamená, že niekto, v našom prípade štát, má určitú povinnost' a jednotlivec si ju môže nárokovat'. Všimnime si, že zabezpečenie celoplošnej starostlivosti a tvorby podmienok na to, aby občania mohli sociálne práva využívat', nemá žiadne striktne predpísané pravidlá. Záväzné medzinárodné právne predpisy síce ukladajú štátom zapracovat' ich do legislatívy, ale nepredpisujú ako.

Spôsoby presadzovania sociálnych práv sú vel'mi rôznorodé. Naznačili sme, aké sú ciele ich implementácie. Sociálne práva ako také sú princípmi, normami a bez konkrétneho spôsobu ich presadzovania (Palovičová 2017, 68) sú len tézami, ku ktorým

\footnotetext{
${ }^{22}$ Nedostatok zdrojov v systéme zdravotníctva rieši štátna administratíva vyňatím určitých diagnóz zo systému zdravotného poistenia a schválením systému doplatkov za výkony i lieky.

${ }^{23}$ Dalo by sa uviest' viacero príkladov, ale problém diskriminácie je jedným z tých, ktorý sa na štátnej úrovni a v rámci EÚ rieši rôznym spôsobom.
} 
sa štát hlási. Premena abstraktných prostriedkov na spôsobilosti (capabilities) ${ }^{24}$ snaha zabezpečit' dobrý - používa sa aj termín plnohodnotný - život svojim občanom je $\mathrm{v}$ súčasnosti plne v kompetencii štátu. Vytvorit’ príležitosti aj pre tých, ktorí čelia nepriaznivým okolnostiam, by malo byt' samozrejmé, ved' štát sa prihlásil $\mathrm{k}$ akceptácii sociálnych práv, ktoré prislúchajú občanom na základe holého faktu, že sú jeho občanmi. Právo na právo (Arendtová 1996, 406) vyžaduje však patrit' k určitému organizovanému spoločenstvu a garantovat' si l'udské práva navzájom predpokladá akceptáciu l'udskej dôstojnosti či idey rovnakého rešpektu. Rola filozofie je v tomto kontexte daná, venuje sa analýze konceptuálnych a argumentačných problémov, normatívnosti l'udských práv a výkladu termínu l'udská dôstojnost' ako ústrednému pojmu l'udských práv, vzt'ahu l'udských práv a pojmov človek, osoba, autonómia a spravodlivost' (Palovičová 2015, 759 - 769). L'udské práva totiž majú zabezpečit', že sa k človeku vo všetkých jeho rolách bude pristupovat' tak, aby ich mohol slobodne využívat'. Sú to základné práva, ktoré majú zabezpečit', že všetky oblasti spoločenskej praxe budú splńnat také minimálne požiadavky, aby $\mathrm{k}$ nim mal každý človek prístup a aby v nich mohol realizovat' svoje poslanie byt' slobodným subjektom“ (Pollmann - Lohmann 2017, 175).

Ak má mat' každý právo prežit' život podl'a svojich predstáv, tak systém by mal riešit' aj otázku rovnakého prístupu k zdrojom, čo však neoliberálna spoločnost', zameraná výhradne na zachovanie osobnej slobody a individuálneho sebaurčenia, odmieta. Neoliberálni myslitelia v otázke implementácie sociálnych práv nemenia svoje stanovisko a priorizujú individuálnu zodpovednost', ale sú si vedomí záväzkov, ku ktorým sa prijatím sociálnych práv zaviazali. $\mathrm{V}$ posledných rokoch preto presadzujú koncept efektívneho altruizmu, ${ }^{25}$ ktorý vyzýva v mene zamedzenia utrpenia či chudoby $\mathrm{k}$ darcovstvu finančných prostriedkov charite. Tá, $\mathrm{v}$ podobe mimovládnych organizácií, má kompenzovat' tie služby, ktoré by mal zabezpečovat' pri implementácii sociálnych práv štát. „Právo na nezávislý život ruka v ruke s inými l'udskými právami založenými na idei l'udskej dôstojnosti nemôže zabezpečit' akokol'vek dobre myslená charita, ale výlučne ústretová politika štátu“ (Sedová, Palovičová 2018, 131). Aj ked’ nie je v kompetencii filozofie posudzovat', či je socioliberálny systém preferovaný v krajinách Európskej únie spravodlivejší voči odkázaným skupinám osôb a štátna sociálna a či zdravotná politika dôsledne uplatňuje princípy rovnosti šancí, dá sa identifikovat', že kompenzačné funkcie štátu sú nakoncipované v prospech väčších skupín

${ }^{24}$ Tento pojem zavádza Sen, čím zároveň spochybňuje Rawlsov pojem rovnosti príležitostí.

${ }^{25}$ Pozri Foltin, M.: Zdôvodnenie l'udských práv v koncepcii efektívneho altruizmu. Filozofia, 74 (8), $622-636$. 
osôb a systém verejných zdrojov ${ }^{26}$ umožňuje väčšiu dostupnost' sociálnych a zdravotníckych služieb.

Vytvorenie materiálnych podmienok pre implementáciu sociálnych práv sa ukazuje ako podmienka efektívneho presadzovania sociálnych práv, a teda dostupnosti služieb, ktoré sú klúčové pre vymožitel'nost' sociálnych práv. V takomto systéme tvorbu systému služieb vo verejnom záujme determinuje princíp solidarity, ktorý ako primárne morálna hodnota umožňuje tvorbu verejných zdrojov a prístup $\mathrm{k}$ zdrojom aj pre tých, ktorí sa na ich tvorbe nepodiel'ajú, lebo nemôžu. Dostupnost' služieb by totiž mala byt' samozrejmá $\mathrm{v}$ prípade akéhokol'vek ohrozenia či individuálnej potreby. Nárokovatel'nost' či vymožitel'nost' podmieňuje štruktúra oprávnení, a tie závisia od kompetencií, ktoré tvoria základný predpoklad pre činnost' právnych predstavitel'ov či úradov (Pollmann - Lohmann 2017, 183).

Právo na sociálne zabezpečenie, zdravotnú starostlivost', dôstojný život či zdravé životné prostredie by teda malo byt' koncipované na základe hodnôt. Ukazuje sa však, že by malo íst' o hodnoty, ktoré fungujú v rámci spoločnosti a jej kultúry dlhodobo a sú jej súčast’ou. Akceptácia individuálnych potrieb a požiadaviek sa buduje na základe rešpektu, teda uznania a akceptácie človeka, a priznaním práva rozhodovat'o sebe. Akceptácia sociálnych práv je uznaním luudskej dôstojnosti, rovnosti príležitostí a rovnosti šancí (Pollmann - Lohmann 2017, 188) a je aj cestou nápravy nespravodlivosti a možnosti vol'by pre tých, ktorí by ju inak vôbec nemali.

\section{Literatúra}

ARENDTOVÁ, H. (1996): Pôvod totalitarizmu. Praha: Oikomenh.

ARISTOTELES. (2011): Etika Nikomachova. Bratislava: Kalligram.

FOLTIN, M. (2019): Zdôvodnenie l’udských práv v koncepcii efektívneho altruizmu. Filozofia, 74 (8), 622 - 636. DOI: https://doi.org/10.31577/filozofia.2019.74.8.3

GOSEPATH, S. (2001): Soziale Menschenrechte. In: Frank, Th. et al. (Hrsg.): Soziale Menschenrechte - die vergessenen Rechte? Berlin: Verlag Dr. Köster, 15 - 42.

HABERMAS, J. (2003): The Future of Human Nature. Cambridge: Polity Press.

HOLMES, S., SUNSTEIN, C. R. (1999): The Costs of Rights: Why Liberty Depends on Taxes. New York: W. W. Norton \& Company.

KÄLIN, W., KÜNZLI, J. (2008): Universeller Menschenrechtsschutz. 2. Auflage. Basel: Helbing Lichtenhahn Verlag.

KRENNERICH, M. (2013): Politik und Bildung Soziale Menschenrechte Zwischen Recht und Politik. Frankfurt am Main: Wochenschau Verlang.

KUKLYS, W. (2005): Amartya Sen's Capability Approach: Theoretical Insights and EmpiricalApplications. Berlin: Springer.

MILLER, D. (1995): On Nationality. Oxford: Oxford University Press.

POLLMANN, A. - LOHMANN, G. (eds.) (2017): Ludské práva - interdisciplinárna príručka. Bratislava: Kalligram.

${ }^{26}$ Princíp tvorby verejných zdrojov na základe princípu solidarity považujú neoliberálni myslitelia za nespravodlivý, ked’že doň primárne prispievajú tí, ktorí z neho nečerpajú. 
NOZICK, R. (1997): Distribuční spravedlnost. In: Kiss, J.: Současná politická filosofie: Praha: Oikoymenh, $205-238$.

NUSSBAUM, M. (2007): Frontiers of Justice. Disability, Nationality, Species Membership. Cambridge - Massachusetts - London: Harvard University Press.

PALOVIČOVÁ, Z. (2017): Ambivalentnost' ludský práv a neurčitost' ich pojmu z pohl'adu filozofie. Bratislava: VEDA.

PALOVIČOVÁ, Z. (2015): Ambivalentnost' l’udských práv z pohl'adu filozofie. Filozofia, 70, (9), $759-769$

PALOVIČOVÁ, Z. (2013): Senova teória spravodlivosti. Filozofia, 68, (4), 265 - 275.

PALOVIČOVÁ, Z. (2014): Spravodlivost' ako problém sociálnej filozofie. Trnava: Univerzita sv. Cyrila a Metoda v Trnave.

RAWLS, J. (1995): Teorie spravedlnosti. Praha: Victoria Publishing.

RAWLS, J. (1997): Politický liberalizmus. Prešov: Slovacontact.

RAWLS, J. (2007): Spravodlivost' ako férovost'. Bratislava: Kalligram.

ROUSSEA, J. J. (2010): O pôvode a prícinách nerovnosti medzi l'ud'mi. Bratislava: Vydavatel'stvo spolku slovenských spisovatel'ov.

SEN, A. (2010): The Idea of Justice. London: Penguin Books.

SEDOVÁ, T. (2008): K pojmu l'udskej prirodzenosti a kultúry a $\mathrm{k}$ ich funkcii v sociálnom poznaní. Filozofia, 68 (8), $657-669$.

SEDOVÁ, T., PALOVIČOVÁ, Z. (2018): Zdravotné postihnutie v kontexte ludských práv. Filozofická reflexia. Bratislava: Veda.

SOUSEDÍK, S. (2010): Svoboda a lidská práva a jejich přirozený základ. Praha: Vyšehrad.

TUGENDHAT, E. (2004): Přednášky o etice. Praha: Oikúmené.

VASAK, K. (1977): Human Rights: AThirty-Year-Struggle: the Sustained Efforts to give Force of Law to the Universal Declaration of Human Rights. UNESCP Courier, 30 (11), 29 - 32.

VŠEOBECNÁ DEKLARÁCIA LUUDSKÝCH PRÁV. Dostupné na: https://www.gender.gov.sk/wpcontent/uploads/2012/06/UDHRvSVK.pdf (Navštívené: 20. 6. 2020).

Táto práca vznikla v rámci projektu VEGA 2/0049/20 Kidei l’udských práv-koncepty, problémy, perspektivy.

Eva Smolková

Filozofický ústav SAV

Klemensova 1

81364 Bratislava 1

Slovenská republika

e-mail: smolkovaeva@gmail.com

ORCID ID: https://orcid.org/0000-0003-1450-8692 